\title{
Consumers' Attitude to the Protest Against Lady Gaga's Concert: An Exploratory Study
}

\author{
Kresno Agus Hendarto \\ Balai Penelitian Teknologi Hasil Hutan Bukan Kayu, NTB
}

\begin{tabular}{|c|c|}
\hline ARTICLE INFO & A B S T R A C T \\
\hline $\begin{array}{l}\text { Keywords: } \\
\text { protest, } \\
\text { classical conditioning model, } \\
\text { expectancy-value theory, } \\
\text { focus group, } \\
\text { qualitative content analysis }\end{array}$ & $\begin{array}{l}\text { Lady gaga is an American singer who has won } 5 \text { Grammy Awards. In the } \\
\text { middle of } 2012 \text {, she was requested to have concert in Jakarta with the } \\
\text { contract value of tens billion. The concert was protested by a number } \\
\text { of groups. The promoter had approached the pressure groups and } \\
\text { negotiated the dressing. However, Lady Gaga's management canceled } \\
\text { the concert for security consideration. The objectives of the study are: } \\
\text { (1) to explore consumers' attitude to the protest for the cancelation } \\
\text { of Lady Gaga's concert; and (2) using classical conditioning and } \\
\text { expectancy-value theory, to explain consumers' attitude to the protest. } \\
\text { The study used focus group to collect data. The collected data was } \\
\text { then transcribed and analyzed by content analysis. The results show } \\
\text { that informants' opinions can be classified into two groups: agreement } \\
\text { and disagreement with the protest for the cancelation of Lady Gaga's } \\
\text { concert. Informants either agree or disagree for some reasons. } \\
\text { Classical conditioning theory can explain either consumer's attitude. } \\
\text { The difference is the object of consumers' attitude who agreed was } \\
\text { Lady Gaga herself, while the object of disagreement was the pressure } \\
\text { group that sponsored the protest. The attitude of the disagreement can } \\
\text { also be explained by expectancy-value theory. }\end{array}$ \\
\hline
\end{tabular}

\section{INTRODUCTION}

Kompas Daily Monday, 28 May 2012, wrote that the American pop singer, Lady Gaga, canceled the concert in Indonesia because of no security guarantee. The cancelation was informed by Lady Gaga's management to the promoter in Indonesia on Sunday (27/5) morning. The promoter, "Big Daddy Entertainment", announced it on Sunday (27/5) afternoon. According to the legal advocate of "Big Daddy Entertainment", Minola Sebayang, the cancelation decided by Lady Gaga's management is due to security consideration. They were 
afraid of the security of the singer, crews, and spectators if the concert went on. Lack of security guarantee resulted in the protest by some pressure groups. Another reason was that the Regional Police of Metro Jaya was reluctant to provide security guarantee through their statement of not recommending the concert.

According to Longman Dictionary (2003), the word protest is classified as a noun or verb. As a noun, protest means a serious complaint to show disagreement or anger about wrongdoing or unfairness. As a verb, protest means saying or doing something to express disagreement or anger about wrongdoing or unfairness. Gene Sharp in Lofland (2003) divides protest into four levels based on the seriousness: (1) symbolic protest or well-mannered protest characterized by organized, non-destructive, and less attractive nature collectively done to express a complaint. Some good examples are procession, parade, assembly, and picketing. The protest is only found in relatively open and transparent society. The authority and the society are prepared to anticipate the action without any refusal/ obstacles; (2) anti-cooperation characterized by refusal to go on the prevailing social norms. It is distinguished by social, economic, and political focus. What are generally found in economic reality are strike, undermining, boycott, etc.; (3) intervention characterized by the deterioration of patterns, policies, and behavioral relation as well as obstructive institutions. Compared to the 2 previous types of protest (symbolic protest and anti-cooperation) this protest has more direct and real challenges. This action involves violence. There are four patterns of intervention protest: (a) harassment, characterized by activities to challenge the target person in unusual manners; (b) system overloading, because of the many intervened processes; (c) blockade, in which protesters temporarily obstruct the movement of people or property of the opposed; and (d) occupation, characterized by "entrance or refusal to leave" any undesired or prohibited places; and
(4) alternative institution, that is the highest level of protest. When the action can replace social loyalty, then the action has achieved the most serious and important level. The action can trigger great changes or even unexpected revolution that would have been impossible in the case of the three other types.

The objectives of the study are: (1) to explore consumers' attitude to the protest for the cancelation of Lady Gaga's concert; and (2) to explain consumers' attitude to the protests using classical conditioning and expectancyvalue theory. The study reviews this issue from the perspective of consumers' behavior. We are sure that consumers' behavior analysis using the research method procedure of psychology, sociology, economy, and anthropology, may provide rich perspectives for the analysis of collective behavior/social movement. On the other hand, we would like to show that collective behavior is also concerned with the consumers' behavior of individuals and group. Mowen \& Minor (2002) state that there are 3 perspectives in the research of consumers' behavior: (1) decisionmaking perspective; (2) experiential perspective; and (3) behavioral influence perspective. In the study, we use the decision-making perspective. The roots of this approach are cognitive and psychological experiences as well as other economic factors.

The difference of this study from the previous studies is that we use actual condition or the ongoing protest. This is in contrast with the study conducted by Smith \& Cooper-Martin (2007); Sen, Gurhan-Canli \& Morwitz (2001); Belch \& Belch (2007), using experimental method in collecting data, and the study by Kozinets \& Handelman (1998); Ovaskainen \& Kniivilä (2005); King \& Soule (2007); Becchetti \& Rosati (2007); Lenox \& Eesley (2009); Pookulangara, Shephard \& Mestres (2011) using observation method in collecting data. The advantage of collecting real-time data is that we can capture what is going on immediately and give 
the data closer to the emic side of the continuum The disadvantage of lack of adequate control to the informants can be overcome because we can immediately capture their emotion. In so doing this study uses focus group method and analyzes it with qualitative content analysis.

\section{Classical Conditioning and Expectancy-value Theory}

Prejudice is concerned with people's perception, behavior, and attitude to someone else or other group. Human's attitude is not congenital, but is acquired through the process of learning along their life (Wibowo, 2009). One of factors that contributes to the shaping of our attitude is social learning process (Baron \& Byrne, 2005) In other words, parts of our attitude are shaped by our interaction with other people or through observation of other people's behavior. Learning theory can be divided into two: behaviorist and cognitive (Assael, 2001). One of the behavioral learning theories is classical conditioning. In this theory, the process of learning occurs when a stimulus is always followed by another stimulus, so that the first stimulus becomes a precursor for another stimulus.

This theory was first introduced by Ivan Pavlov, a Russian psychologist. He was interested in how animals and humans learn. He investigated human's process of learning through experiments in dogs. For his hard work, he received a noble award in psychology. Limbad (2013) mentions that classical conditioning is a four-step learning procedure involving reflexes:

1. Unconditioned Stimulus (US) - stimulus that evokes an unconditioned response without any prior conditioning (no learning needed for the response to occur).

2. Unconditioned Response (UR) - an unlearned reaction/ response to an unconditioned stimulus that occurs without prior conditioning.

3. Conditioned Stimulus (CS) - a previously neutral stimulus that has, through conditioning, acquired the capacity to evoke a conditioned response.

4. Conditioned Response (CR) - a learned reaction to a conditioned stimulus that occurs because of prior conditioning.

Figure 1 shows that unconditioned stimulus is always followed by conditioned stimulus, so that unconditioned response becomes a precursor for conditioned response. Gradually, people will learn that when unconditioned stimulus appears, then conditioned stimulus will follow. Wibowo (2009) informs an example of a child who sees his mother serving tea and cake for her guests and talking to them happily. In this case, unconditioned stimulus is serving tea and cake to the guests, while the

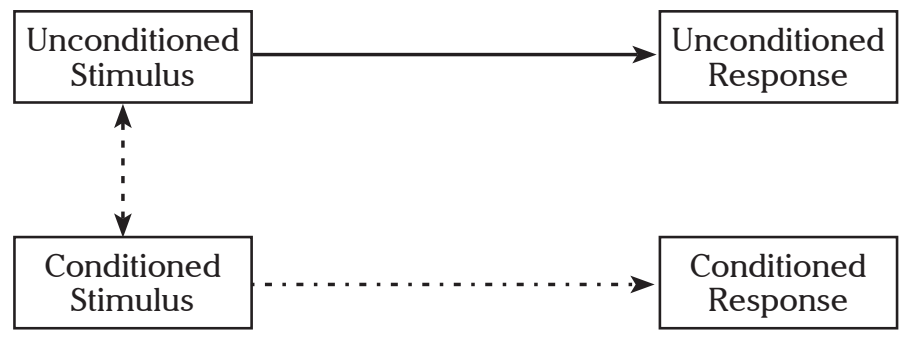

Emphasis: Association repetition and continuguity

Figure 1. Classical Conditioning Source: Assael (2001) 
conditioned stimulus is the happy situation. When the child grows up, he will have positive attitude to the guests who call to his home as a result of learning through classical conditioning. He will welcome guest happily although the response to unconditioned stimulus (providing tea and cake) is not made, because the response to conditioned stimulus is so strong, so that he is always in happy condition when welcoming his guest to his home. In marketing, advertisement and market communication are common forms of classical conditioning theory. In general, this theory can be used to advertise the products with low involvement (Hawkins, 1998). This is because the classical conditioning theory is the most effective when there is emotional involvement. Several studies in advertisement have supported this theory (e.g. Bierley, McSweeney \& Vanniewkerk, 1985; Stuart, Shimp, Engle, 1987; and Shimp, Stuart \& Engle, 1991).

Friedman \& Friedman (1979) state that there are several types of product endorsers such as particular expertise, top management, and celebrity. Of such types, the most commonly used are top management and celebrity in sport, film, or other entertainment fields (Atkin \& Block, 1983).
This is proven by Freiden (1984) who compares between celebrities, CEOs, experts, and typical consumers in providing product endorsement. The comparison revealed that celebrities are the best because they have high scores in the dimensions of trustworthiness, believability, persuasiveness, and likeability. Assael (2001) also reveals that celebrities are effective endorsers because according to reference group theory, they are the symbol of consumers' aspiration. The reference group theory provides comparison in which consumers can evaluate their attitudes and behaviors. Although consumers are not celebrities, or will become celebrities, most consumers pursue some symbols to make them identical with the group. They purchase the products endorsed by celebrities. In this case, celebrities are defined as those who are popularly known due to their success in particular field not directly related with the product class (Friedman, Termini \& Washington (1977).

Based on the assumption that "what is beautiful is good", celebrities are frequently used as the endorsers of particular brands. Celebrities are used as the endorsers because of their physical attractiveness and status (Friedman \& Friedman

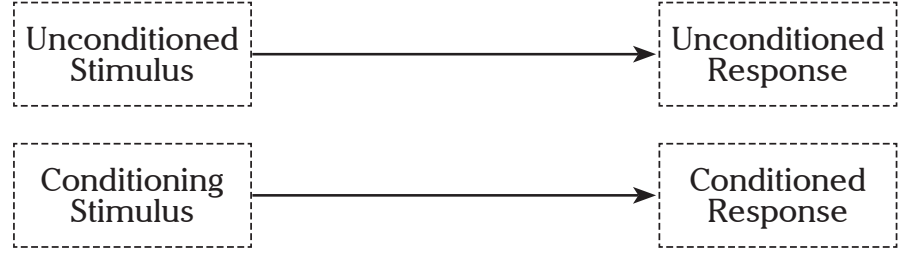

Application to Market Communication

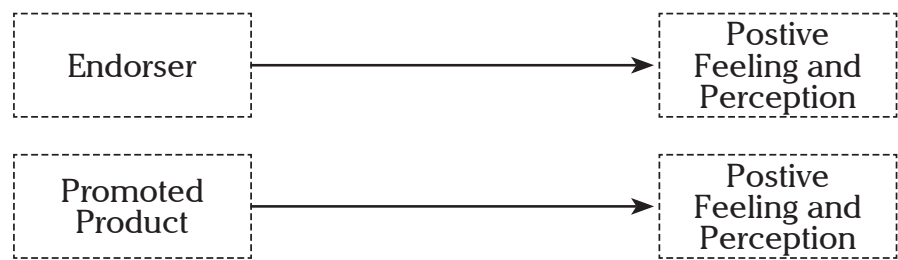

Figure 2. Classical Conditioning Paradigm in Market Communication Source: Limbad (2013) 
1979; Singer 1983; Kamins, 1990). However, results of the other study also revealed the contrary finding. In other words, the physical attractiveness of an endorser does not necessarily have good effect on a product (Holahan \& Stephan 1981; Caballero \& Pride 1984). Figure 2 shows that, in classical conditioning theory, consumers will learn the correlation between UC (endorser) and CS (product) through repetitive exposure. This can be seen from the endorsement made by celebrities to particular products. Frequently, the use of celebrities as the spokesperson derives from the belief that the combination of products and celebrities will improve consumers' perception on particular products (Kamins \& Gupta, 1994). Some studies, such as those conducted by Kamins (1990); Kamins \& Gupta (1994); Till \& Busler (2000), suggest that the combination is a match-up hypothesis, where the suitability of celebrities and products will effectively increase the favorable credibility and attitude for particular brands.

The study conducted by Till, Stanley \& Priluck (2008) has verified the match-up hypothesis using the classical conditioning theory. They: (1) used celebrities to provide conditional general effects; (2) tested the suitability of brands and celebrities; and (3) explored the power of attitudes to brands through celebrities. Results of the analysis suggested that conditional with celebrities to attitudes to brands is robust and enduring. More recent studies have been conducted by Chen, Chang, Besheratb \& Baack (2013). The objectives of their studies are to test the effect that celebrity has as the spokesperson on several brands. In their studies, they used classical conditioning theory in explaining the issue. Results of their analysis revealed that consumers' perception is not affected by the number of brands endorsed by celebrity. Conditional response to the first brand endorsed is relatively permanent. More importantly, it is not reduced when celebrities endorse the following brand. Meanwhile, conditional response to the following brand will be more robust when there is a consistent suitability with the first endorsed brand.
Salkind (2009) reveals that most theories tend to be established on other theories. For example, Erikson's theory of psychosocial development is based on Freud's psychoanalysis theory. Although Erikson's theory is different from Freud's theory, Erikson's theory still uses similar basic principles as that in Freud's theory. Such is also the case for Feather's theory (1992) which suggests that expectation-value theory has been extended in various forms, one of which is applied in working situation in Mitchell's instrumental theory (1982); Vroom (1964); working forms concept in Bandura's social cognitive theory (1986); in decision making under uncertainty in Kahneman \& Tversky's prospect theory (1979, 1992); attitude development in Fisben's \& Ajzen's reasoned action (1975, 1980) and Ajzen's planned behavior theory (1991).

Fishbein \& Ajzen (1980) propose a model of attitude formation postulating that the sum strength of our beliefs and their concurrent, affective evaluation of the beliefs, combines to determine attitudes toward performance of an action. The attitude then influences our intentions to perform the act and that the intention has a direct influence upon our behavior. Sears, Freedman \& Peplau (1985) mention that in this theory, the decision is made on the basis of (1) the value of possibly made decisions; and (2) the degree of expectation about the result of the decision. This theory is frequently used to examine persuasion. Persuasion is defined as the explicit attempt to influence belief, attitude, and behavior (Mowen \& Minor, 2002). Taylor, Peplau \& Sears (2009) added that according to this theory, the formation and transformation of the attitude are derived from the loss and benefit calculation, of which people will choose the best one. For example, in a general election with 2 candidates: candidate $\mathrm{A}$ is the incumbent, and $B$ is the challenger, and according to the survey results, both have equally good scoring. When we are going to vote, we consider expectation and value of our vote. We may think of the outcome when we vote $B$ (who is proven to keep good 
governance in other region, only backed-up by few political parties, with no similar experience, etc.). The same holds when we vote A (backed up by many political parties, sustainability of ongoing programs, etc.). If we finally vote $B$, then back up by many political parties and sustainability of ongoing programs are not equivalent to the expected transformation of governance and good track record. In other words, this theory assumes that humans are active and rational decision makers.

\section{METHODS}

The data of the study was collected through focus group method. This method of data collection was based on the works of Paul Lazarsfeld, Robert Merton and their colleague from University of Columbia in the 1940s (O'hEocha, Comboy \& Wang, 2010). Churchill Jr (2001) states that in marketing study, focus group is proven to be productive for: (1) making the hypothesis for further quantitative testing; (2) providing information useful in the development of questionnaires; (3) providing basic information about the product category; and (4) securing the impressions about the new product concepts. In addition, focus group is used for: (1) exploratory purpose: to understand why and how the market behaves in previous, current, and future times; (2) diagnostic purpose: to identify the sequence of problem, expectation, and vulnerability of market segments; (3) development purpose: to formulate the goods/ services/communication of product concept; and (4) soft concept testing (Kennedy, 2002). Krueger (1994); Rakow (2011) also states that focus group is more natural than in-depth interview, because informants both influence and are influenced, just like in the real world. This statement is in line with Kitzinger's (1995) which states that focus group is very useful to explore people's knowledge and experiences, and may test not only what people think but also why people think that way.

The research conducted by Reid \& Reid (2005) were intended to compare between face to face (FTF) focus group and computer-mediated communication (CMC) focus group. Comparison is made on the basis of outcome, process, and subjective measures. Results of the analysis revealed that for equal output, $\mathrm{CMC}$ requires twice longer time than FTF because participants in $\mathrm{CMC}$ have to type the answers. However, there is no difference in number of new idea/replies given by focus group participants. Even better, CMC may reduce the obstacles commonly found in FTC (some participants are too introvert and some others are dominant). Therefore, we use focus group that employs the radio. In that way, informants of focus group do not have to write the response. Accordingly, it takes less time. In addition, like $\mathrm{CMC}$, the informants do not have to stand face to face which means greater anonymity to ensure greater contribution in focus group.

\section{Population and Sample}

Although it is not intended for generalization, the population of the study is the people who are covered with and listen to the program of "Panorama Jogja Malam", a program broadcast by RRI Programa 1, Yogyakarta. Churchill Jr (2001) suggests that the primary emphasis of an exploratory study is the identification of new ideas and inputs. Further, it is said that an exploratory study seldom uses probability sampling. Therefore, the study uses saturation sampling method. Saturation sampling is defined as the obtaining all elements of sample in a particular population that have the characteristics expected by the researcher (Black \& Champion 1976). The sample of the study includes the people who: (1) call/ send SMS (Short Message Service) to "Panorama Jogja Malam" at Radio Republik Indonesia (RRI) programa 1 Jogjakarta; and (2) voluntarily give opinion about the theme and questions asked.

The data collected in the study is primary data of recorded conversation between informants and the host. At the initial part, the host as a moderator led the discussion and gives brief narration. After that he asked for opinions from informants. The 
opinion was recorded and then transcribed.

\section{Data Processing and Analysis}

The already transcribed recorded focus group was then analyzed using content analysis. Krippendorff (2004) defines content analysis as a research technique for making replicable and valid inferences from data according to their context. Although content analysis is the first time used in the field of communication, this method has been employed in other fields for exploration, theory development, hypothesis testing, and applicative studies (Smith in Frechtling \& Boo, 2012).

Berelson (1952) informs that in content analysis, validity is not a significant problem. With carefully made operational definition and good and appropriate indicators, the coding sheet is assumed to be able to measure what it should measure. Meanwhile Kassarjian (1977) mentions that validity test in content analysis may adequately use content validity or face validity. What we did was delivering a letter mentioning the objective of study, transcript, and coding sheet to the researcher at Center for Cultural and Popular Media Analysis. In return we obtained feed back in the forms of qualitative inputs and comments about the coding sheet. Then based on the opinions and suggestions, we changed some operational definitions in the coding sheet.

In addition to face validity testing, the coding sheet must have high reliability. Kaplan \& Goldsen in Eriyanto (2011) states that the importance of reliability lies on that the obtained data is independent of events, instruments, or the men who do the measurement. Furthermore, the reliability test intends to see if the coding sheet can result in similar outcome when it is performed by different persons. There are 3 ways of the testing of coding sheet reliability (Krippendorff, 2004): stability, reproducibility, and accuracy. Because of its simple nature, most researchers using content analysis prefers reproducibility. The same holds for the study. In the study, reliability was tested by coefficient of reliability (intercoder reliability). Neuendorf (2002) mentions that content analysis is useless unless there is measurement of intercoder reliability. Even Tinsley \& Weiss (2000) suggest that data interpretation is not valid without this measurement. This is in line with what Hayes \& Krippendorff (2007) inform that intercoder reliability is a critical component in content analysis. Holsti (1963) provides the following formula of intercoder reliability:

$R \frac{2\left(\mathrm{C}_{1,2}\right)}{\mathrm{C}_{1} \mathrm{C}_{2}}$

Where $\mathrm{C}_{1,2}=$ the number of category assignments on which all coder agree; and $\mathrm{C}_{1}, \mathrm{C}_{2}=$ the sum of all category assignments by all coder. Qualitative content analysis is made after validity and reliability testing. Analysis is contextualizing the transcribed recorded focus group. The contextualization is performed by coding the consensus and difference among the informants and presents the quoted discussions to support the argumentation.

\section{RESULTS AND DISCUSSION}

The preparation of coding sheet is consulted to a researcher at the Center for Culture and Popular Media Research. The objective of this consultation is to test the content validity of coding sheet. What we did was delivering a coding sheet and a letter explaining the objective of the study. Then we got feedback and qualitative comments from the experts from the Center for Culture and Popular Media Research. The feedback and qualitative comments were then made as the basis to improve some operational definitions to match with the ones used by the experts (see Appendix 1 and 2). After that, with the help of the researcher from University of Charles Sturt and Institute of Social Studies, the reliability of the coding sheet was tested.

There was a difference in determining the upper score of acceptance of reliability coefficient. Krippendorff (2004) reports that the lower score of acceptance of reliability coefficient is 0.8 ; 
Scott in Hasrullah (2001) put it above 0.75; while Berelson (1952) informs that the coefficient score is between 0.79 and 0.96 . The calculation of reliability in this phase shows the score of $=0.85$ or above the score described by Krippendorff and Scott, and was between the scores suggested by Barelson (see Appendix 3).

\section{General Description}

Coding sheet preparation was consulted to a researcher at the Center for Cultural and Popular Media Analysis. After that, with the support of 2 researchers from the Institute of Social Studies and Charles Stud University, the reliability was tested. Reliability was tested by asking the two researchers (coder) to fill up the coding sheet. The results were then compared and similarities between the coders were calculated.

Compared to in-depth interview, focus group is very effective to capture the information about social norms and different opinions or views in a population (Wahyuni, 2012). This is due to the interaction among participants. Opinion from an informant may influence opinion from another informant. From the results of focus group, the chronology of the protest against Lady Gaga's concert can be illustrated in Figure 3.

Figure 3 show that initially Lady Gaga and her manager received proposals from promoters to have a concert in Indonesia. Among the proposals received, the proposal submitted by Big Daddy Entertainment (BDE) was approved. The next step was that BDE sought the required permits for the concert from the Headquarter of the Indonesian Police. Temporary permit (visa) from the Tourism Office of DKI Jakarta had been obtained. In the meantime, they sold tickets to the public. Fifty two thousands tickets sold at the price of Rp 465 thousand up to Rp 2.25 million were sold out. Hidayat, Agustia, Sukma, Hayati, Muryadi (2012) state that the permit would be granted soon after they got recommendation from different offices

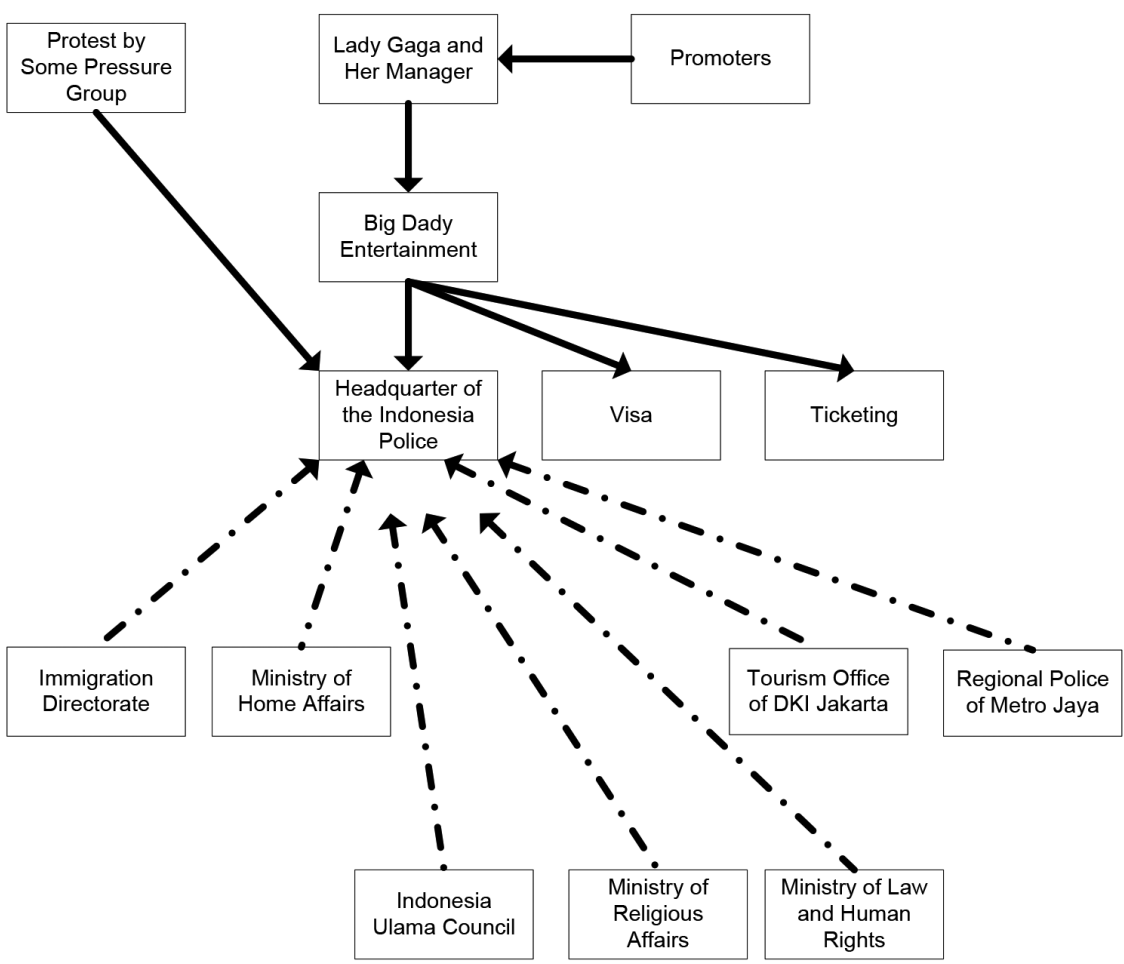

Figure 3. Chronology of the Protest against Lady Gaga's Concert 
such as the Immigration Directorate, Ministry of Home Affairs, Tourism Office of DKI Jakarta, and the Regional Police of Metro Jaya. Different from the standard requirement for other permits, in particular for Lady Gaga's concert, other institutions were authorized to provide recommendation to the Headquarter of the Indonesian Police. They were MUI (Indonesia's Ulama Council), Ministry of Religious Affairs, as well as Ministry of Law and Human Rights. Figure 2 also shows that the pressure groups protested to force the target, the state represented by the Police, not to grant the concert permit.

As what Visentim, Colucci \& Marzocchi (2013) had done, before conducting the focus group the discussion leader provided general description about Lady Gaga, to frame the discussion, based on several sources (such as magazine, television, and newspaper). For approximately 50 minutes, there were 13 informants who gave opinion. Eleven informants gave opinion via phone and two informants gave opinion via SMS. By gender, of 13 informants, two were females, and the remaining were males. By location, informants came from Bantul (23\%), Kota Jogjakarta (23\%), Purworejo (15\%), Sleman (7\%), Magelang (7\%), Klaten (7\%). The remaining $15 \%$ was not identified.

\section{Why did informants agree with the cancelation of the concert?}

Attitude is defined as a mental and neural condition of preparedness which is organized through experience that generates a directed and dynamic influence to individual responses to any relevant object or situation (Allport in Dharmmesta, 1998). Meanwhile Wade \& Tavris in Orth \& Holancova (2003) define attitude as a relatively stable opinion that contains cognitive and emotional elements. Baron \& Byrne (2005) suggest that in general, psychologist uses the term to refer to our evaluation of social aspects and how the evaluation results in the feeling of like or dislike to the issue, idea, person, social group, object, or even dessert. Almost similarly Schuman in Franzoi (2009) defines attitude as either positive or negative evaluation from an object. What is meant by object may be person, thing, event, or issue. When we use the word like, dislike, hate, good and bad, we are describing our attitude.

The same holds for the attitudes shown by the informants in the discussions. The followings are some reasons of the informants agreed with the cancelation:

When you build a house, you have to obtain the construction permit in advance and development follows. That's it. Well, in this case no permit has been obtained, but they already sold the tickets. That is illegal. Get the permit in advance.

Well, yes this comes from ...a free and liberal country, USA, in New York, right. Such this case occurred some years ago, there was a concert, finally was approved, what was that.. erotic, yes ever.. May be it was more vulgar, I think Lady Gaga is ...... Like to other neighboring countries (Lady Gaga), failed to enter. If we had allowed her to enter Indonesia what would Indonesia's image be.. ? Right?

It is not necessarily performed considering that the neighboring countries had refused too. Our image would have been damaged.

Lady Gaga failed, it was closely related to the management, preparation, and the like. If it did occur, the security would have been endangered.

I ... love Indonesia. If it was performed, what Indonesia would have been. You see, the management and spectators could give impacts, ....

... And remember that Indonesia is a democracy; both majority and minority deserve attention. 
I don't agree with the concert because it will cause riots that may endanger lives and properties.

I absolutely agree with the cancelation because it is suspected as the expansion of liberalism from America to Indonesia and it was responded quickly and wisely by our state organs. Avoiding discrepancy of very expensive ticket.

Why did informants disagree with the cancelation of the concert?

While some informants disagreed with the cancelation of the concert, in the discussion it was disclosed that some informants had disagreed with the protest for cancelation of the concert. Some of them are presented in the following:

Yes, the cancelation of the concert, well as a human being I am expressing Ina lilahi Wa Ina Illaihi Rojiun (All that belong to Allah will return to Allah). If the concert was canceled by Lady Gaga's manager, it means that the manager plus the committee of the concert will have to hold responsibility for the purchased tickets; but if the reason is security, well I think it is questionable. Is Indonesia not safe? I think Indonesia is safe and secure because we have professional and competent police. It is a matter of morality then. Those whose morality is bad or poor, even without Lady Gaga will still be bad. Now about the accusation that Lady Gaga worship the Satan. Indeed Satan is created by God to tempt human beings. It depends on us whether we are tough or not. We should not surrender to Satan. On the contrary, we have to conquer Satan.

The more heartbreaking problem is that our democracy is now in danger. Freedom of expression has been infiltrated by some pressures and threats.

And I think the spectators are wise enough to value, I just see it is a performance, not more, not an appeal to commit negative actions, and of course I will be selective that when we watch dangdut, well, dangdut which may be more vulgar than Lady Gaga and is watched by children, that's it. Dangdut in north beach is watched by little children, and then they have negative thinking, they will commit negative action. But when I see it as a performance for visual and auditory entertainment purpose, then I think it is positive.

Regarding with the morality, it is individual concern. And I think the spectators can evaluate it. I think it is a performance, not an appeal to commit negative actions. I think we have to be selective.

Why should we care for other people's business? Look the poor integrity of our officials, we fail to make them better, you see?" "About satanic concern, I think I agree with Bu Harni (previous opinion), right? Satan is everywhere; never shall we get tempted by them. And Lady gaga is not a Satan, she is a human being. That's all, I think".

So the people who disagree do not have any rational argument. And this is a serious disadvantage for our...nation. Particularly for our foreign exchange and tourist. We expect foreign tourist to enter our country, right? So I think there is a political interest here. The people who disagree are anti-America, because they consider USA is atheism, you see. They think that way. And now another example, we would have had mutual exercise with USA, and some of us disagreed. In Situbondo or whatever it is. Well yes, because they are conflict-seekers. Because of that at present time many people put forward violence."

Explanation to the different attitudes to the cancelation of the concert 
In general, definition of prejudice until now derives from Alport (Crandall \& Warner, 2005), that is the antipathy based on wrong and rigid generalization; prejudice can be felt/ expressed to particular groups or persons to which the person belong to. It is also suggested that attitude is a prejudice only when the attitude violates the prevailing important norms or values that have been accepted as a culture. Alport also suggests that prejudice is irrational and lack basis in fact and is unfounded. Meanwhile in this study, we use Crandall \& Eshleman's definition (2003). They suggest that prejudice is a negative evaluation to particular social group or negative evaluation to particular individuals based on the membership.

Therefore, prejudice is an attitude deriving from a clear combination of action, tendency and belief. Negative evaluation characterizing the prejudice is frequently supported by negative belief; this is what is called stereotype. Stereotyping means generalizing (Myers, 2009). Boerce (2008) informs that stereotype is a group of characteristics attributed to a group of people without any logical and rational consideration. For example, we tend to say that men always use logics while women only use emotion. In many cases, men are stronger than women. Or even, women with shrimp-shaped backbone are stronger in making love, etc. Because prejudice is an attitude, then prejudice "does not come instantly", but it derives from social learning.

Social learning can be through classical conditioning or instrumental conditioning, in the theory of classical conditioning, there are 3 primary concepts: (1) repetition; (2) stimulus generalization; and (3) stimulus discrimination. Repetition increases the strength of association between the conditioned stimulus and unconditioned stimulus and slows down the process of forgetting (Schiffman \& Kanuk, 2007). Meanwhile stimulus generalization is the opposite of stimulus discrimination. Both are related to the ability of individuals both in making generalization and distinguishing responses from a nearly similar stimulus. In marketing, generalization is found in "me too" products. For example, most packaged mineral-water products use color. This is because Aqua, a very popular brand, uses the color. It is expected that consumers generalize the packaged water products to Aqua (Prasetijo \& Ihalauw, 2005).

From the discussion, informants knew that the protest against Lady Gaga's concert by pressure groups from some media, either electronic, printed, or the internet. Some pressure groups that protest against Lady Gaga's concert were described as the groups that are known for their frequent protests and violence. Consequently, the consumers who like the cancelation of the concert think that repetition of what they learn will occur again (protests followed by arbitrary actions, judgment, and violence). On the other hand, they also seek out who Lady Gaga is and how the concert is performed. Stereotype that Lady Gaga is a transsexual, adorer of Satan, female-lover, gay icon, immoral, sexy appearance, distorting lyrics, and so on, for those who agree with the cancelation of the concert strengthens their attitude. This is in line with Kunda's statement (1999). He states that stereotype has impact on information processing. Stereotype-relevant information is frequently processed faster and is remembered better (Dovidio, Evans, Tyler, 1986). In other words, stereotype causes consumer consistently pays attention to certain information that is consistent with his stereotype. O'Sulivan \& Durso (1984); Kunda \& Olesen (1995) also suggest that when the obtained information is different from the acquired stereotype, the person will actively suppress or slightly alter his stereotype. The objective is to make the information received consistent with his stereotype. The studies conducted by Cantor \& Mischel (1977); Yarmey (1993) also support the idea that when the stereotype is active, individuals are likely to interpret other people's action consistently with the stereotype. From the result of focus group, although the concert organizer 
had attempted to urge Lady Gaga to wear decent clothing, people used other reasons for agreeing the cancelation of the concert (e.g. indecent lyrics, gay icon, lesbian, etc).

\section{Explanation to the informants' disagreement with} the cancelation of the concert

In expectancy-value theory, people respond something based on the received incentive. In this theory, attitude formation and attitude change derive from the pros and cons process of various attitudes, the best one of which is selected (Taylor et al., 2009). In other words, people will depend on the possibly received impact based on subjective calculation, which may be different among different people.

Informants think that the reimbursement of ticket price will not equal to what they have spent, including information seeking, the time spending in queue, transfer fee, disappointment, etc.). To prevent more serious disadvantage, they disagreed with the cancelation. Informants who think that there are technological disadvantages due to the failure of transfer of technology in staging, sound system, and performance disagreed with the cancelation. The same holds for the informants who see that Lady Gaga's concert will attract foreign tourists to watch, that in turn will give revenue for the state. The informants disagreed with the protest. Informants who feel that the state (represented by the police) is defeated by pressure groups disagreed with the protest to the cancelation of the concert. Likewise, the informants who uphold democracy (represented by freedom of speech and expression) disagreed.

One thing interesting here is the suggestion from informants who disagree with the the protest for the cancelation of the concert. $\mathrm{He}$ suggested:" what they have to do when they do not expect the performance or ideology was only 1, which is, influencing their members not to buy the tickets and not to watch. That's all. That's the way. Meanwhile the interest of the people who like it has to be protected. In other words, he said that he dislike the intervening protest. But he tolerates anti-cooperation protest (boycott).

Informant's disagreement can also be explained using classical conditioning theory. The difference with informants' agreement is the object of prejudice. The object of the informants' agreement with the cancelation of the concert was Lady Gaga, while the object of the informants' disagreement was pressure groups sponsoring the protest. When the pressure groups sponsoring the protest are out-groups, then informants will take different (negative) attitude from sponsoring groups. (Ingroup is the group where an individual become the member; out-group is any group other than in-group. Group here is not identical with religion. That is, when the pressure groups that protesting was ideologically Islam, not all Muslim informants agreed with the protest).

\section{MANAGERIAL IMPLICATIONS}

Referring the results of the exploratory study, the promoter of the show is advised to take the following actions: first, it is necessary that we obey and conform to the prevailing rules. Before selling the show tickets, the promoter has to make sure that the required licensing and permits have been obtained. With the currently practiced "one-stop licensing service", in which all licensing services are integrated uniformly, license will be more easily obtained. Second, in the social interaction and interrelation among individuals and groups, conflict may naturally occur. Conflict occurs due to obstructed communication, distrust, and lack of transparency. On the other hand, one of the government programs currently is ensuring social cohesiveness and social restoration through education of diversity tolerance and dialogues among the people. This means that sustainable dialogue between entrepreneurs (in this case the show promoter) and primary and secondary stakeholders deserves adequate attention. The dialogue should be sustainable rather than incidental. In other words, communication has 
to be adequate and frequent. The government is obliged to facilitate the dialogues. Third, it is necessary to have back up strategy particularly in show location. When they see the likely resistance from secondary stakeholders for particular reasons, then back up strategy is needed to ensure the ongoing show. In addition to minimize financial loss, back up strategy may retain corporate image (show promoter) in consumers' perception. Fourth, in case the steps have been taken but resistance is still present, it is advisable to sell tickets online/electronically to facilitate consumers to get the financial return without any unnecessary extra costs.

\section{CONCLUSION}

The objective of the study is: (1) to explore consumers' attitude to the protest the cancelation of Lady Gaga's concert; and (2) to explain consumers' attitude to the protest using classical conditioning theory and expectancy-value theory. As an exploratory study, the data was collected by focus group through RRI Programa 1. The results of analysis suggest that informants' opinions can be classified into 2: agreement and disagreement with the cancelation of Lady Gaga's concert. Some reasons were given to informants' agreement and disagreement. Classical conditioning theory can explain the attitude of both types of consumers' attitudes. The difference is that the object of consumers' agreement was Lady Gaga herself, while the object of the consumers' disagreement was the pressure groups sponsoring the protest. Consumers' disagreement can be explained by expectancy-value theory.

The study contributes to the improved understanding of consumers' preference in responding to the cancelation of Lady Gaga's concert. Classical conditioning theory is a basic principal in psychology, which is commonly used in marketing, if a stimulus appears repeatedly followed by other stimulus, then the first stimulus will be considered as the clue for the appearance of the second stimulus. In other words, if the first stimulus appears then the second stimulus will come soon. This leads them to give similar response to the first stimulus as when the second stimulus appears. Therefore, social learning may result in prejudice.

Consumers' disagreement with the cancelation of Lady Gaga's concert was strongly influenced by their evaluation to the possibly received advantage and disadvantage. They will compare the benefits or losses that possibly result. Expectancy-value theory assumes that consumers are rational and active decision makers who act on the basis of the possibly received impact. The impact with the highest incentive (the most beneficial) will be preferred by the consumers. In addition, they will prefer the lowest negative impact.

The study uses focus group in collecting the data. Using the RRI Programa 1 Jogjakarta, the main limitation of the data collection method is that informants could not change the opinions already given. This results from the limited tools (only one phone line was available). However, with real-time data collection and analysis of both agreement and disagreement with the protest has distinguished this study from the others. Like other qualitative method, it is likely that a case study is less able to control the researcher bias. One of the characteristics of qualitative research is that the researcher is the key instrument (Danim, 2002). Therefore, the use of inter-coder reliability is expected to minimize the researcher's bias.

As an exploratory study, the study opens chance for further studies. Some factors that may predict consumers' attitude to the protest (such as values of individualism; freedom; religiosity; trust to the object of the protest; as well as pressure group credibility) need to be studied in future time. In addition, in the future, the use of attribution theory, reference group theory, and social identity theory can also be used to understand, explain and predict consumers' attitude to the groups who protest Lady Gaga's concert. 


\section{Acknowledgement:}

The National Priority Research of Masterplan for Acceleration and Expansion of Indonesia's Economic Development in 2011We gratefully acknowledge the comments made by Aneka Prawesti Suka from Institute of Social Studies, Anna Susilaningtyas from the Center for Culture and Popular Media Research., Lukas Rumboko Wibowo from Charles Sturt University., M. Safiq from Faculty of Economics and Business, Gadjah Mada University., Arlin Setyaningsih, Agus Pramono, Jujuk, and Nanik Kusumo Radio Republik Indonesia PRO 1 FM, Jogjakarta, as well as the anonymous reviewers for their comments on this paper. An earlier version of this paper was presented on "The Doctoral Colloquium and Conference 2012, at Faculty of Economics and Business, Gadjah Mada University, Jogjakarta.

\section{REFEREN CES}

Ajzen, I. (1984). The theory of panned behavior. Organizational Behavior and Human Decision Processes, 50, $179-211$.

Ajzen, I., \& Fishbein, M. (1980). Understanding attitudes and predicting social behavior. Englewood Cliffs, N.J.: Prentice-Hall. Assael, H. (2001). Consumer behavior and marketing action, $6^{\text {th }}$ Edition. Ohio: Thomson Learning.

Atkin, C., \& Block, M. (1984). Effectiveness of celebrity endorsers. Journal of Advertising Research, 23 (1), 57-61.

Bandura, A. (1986). Social foundations of though and action: A social cognitive theory. Englewood Cliffs, N.J.: Prentice-Hall.

Baron, R.A., \& Byrne, D. (2005). Psikologi Sosial, $10^{\text {th }}$ Edition. Translated by: Djuwita, R., Parman, M.M., Yasmina, D., \& Lunanta, L.P. Jakarta: Penerbit Erlangga.

Becchetti, L., \& Rosati, F.C (2007). Global social preferences and the demand for socially responsible products: Empirical evidence from a pilot study on fair trade consumers. World Economy, 30 (5), 807-836.

Belch, G.E., \& Belch, M.A. (2007). The aplication of expectancy value operationalization of fuction theory to examine attitudes of bycotters and nonboycotters of a consumer product. Advances in Consumer Research, 14, 232-236.

Berelson, B. (1952). Content analysis in communication research. New York: Hafner Press.

Bierley, C., McSweeney, F.K., \& Vanniewkerk, R. (1985). Classical conditioning of preferences for stimuli. Journal of Consumer Research, 12 (3), 316-323.

Black, J.A., \& Champion, D.J. (1976). Methods and issues in social research. Baltimore: John Wiley and Sons Inc.

Boerce, C.G. (2008). Psikologi sosial. Translated by: Taniputera, I. Jogjakarta: Prismasophie.

Caballero, M.J., \& Pride, W.M. (1984). Selected effects of salesperson sex and attractiveness in direct mail advertisements. Journal of Marketing, 48, 94-100.

Cantor, N., \& Mischel, W. (1977), Traits as prototypes: Effects on recognition memory. Journal of Personality and Social Psychology, 35, 38-48.

Chen, A.C., Chang, R.Y., Besherat, A., \& Baack, D.W. (2013). Who benefits from multiple brand celebrity endorsements? An experimental investigation. Psychology and Marketing, 30 (10), 850-860.

Churchill Jr, G.A. (2001). Basic marketing research, $4^{\text {th }}$ Edition. Chicago: The Dryden Press

Crandall, C.S., \& Eshleman, A. (2003). A justification-suppression model of the expression and experience of prejudice. Psychological Bulletin, 129 (3), 414-446.

Crandall, C.S., \& Warner, R.H. (2005). How a prejudice is recognized. Psychological Inquiry, 16 (2/3), $137-141$.

Danim, S. (2002). Menjadi peneliti kualitatif. Bandung: Pustaka Setia.

Dharmmesta, B.S. (1998). Theory of planned behavior dalam penelitian sikap, niat dan perilaku konsumen, KELOLA Gadjah Mada University Business Review, 18/VII, 85-103.

Dovidio, J.F., Evans, N., \& Tyler, R.B. (1986), Racial stereotypes: The contents of their cognitive representations. Journal of Experimental Social Psychology, 22 (1), 22-37.

Eriyanto. (2011). Analisis isi: Pengantar metodologi untuk penelitian ilmu komunikasi dan ilmu-ilmu sosial lainnya. Jakarta: Kencana.

Feather, N.T. (1992), Expectancy-value theory and unemployment effects. Journal of Occupational and Organizational Psychology, 65, 315-330.

Fishbein, M., \& Ajzen, I. (1975). Belief, attitude, intention, and behavior: An introduction to theory and research. Reading MA: Addison-Wesley.

Fishbein, M., \& Ajzen, I. (1980). Understanding attitudes and predicting social behavior. New Jersey: Prentiss-Hall, Inc. 
Franzoi, S.L. (2009). Social psychology, $5^{\text {th }}$ Edition. New York: McGraw-Hill Publishing Company.

Frechtling, D.C., ad Boo, S. (2012). On the ethics of management research: An exploratory investigation. Journal of Business Ethics, 106, 149-160.

Freiden, J.B. (1984). Advertising spokeperson effects: An examination of endorser type and gender on two audiences. Journal of Advertising Research, 24, 33-41.

Friedman, H., Termini, S., \& Washington, R. (1977). The effectiveness of advertisement utilizing four type of endoersers. Journal of Advertising, 6, 22-24.

Friedman, H., \& Friedman, L. (1979). Endorser effectiveness by product type. Journal of Advertising Research, $19,63-71$.

Hasrullah (2001). Megawati dalam tangkapan pers. Yogyakarta: LKiS.

Hayes, A.F., \& Krippendorff, K. (2007). Answering the call for a standard reliability measure for coding data. Communication, Methods and Measures, 1, 77-89.

Hidayat, B., Agustia, R., Sukma, A., Hayati, I., \& Muryadi, W. (2012, 28 May-3June). Panas-dingin karena Gaga. Tempo, 34-37.

Holahan, C.K., \& Stephen, C.W. (1981). When beauty isn't talent: The influence of physical attractiveness, attitude toward women and competence on impression formation. Sex Roles, 7, 867-876.

Holsti, O.R. (1963). The quantitative analysis of content. In Robinson, J.A. (Ed.), Content analysis: A handbook with application for the study of international crisis, (pp. 37-53). Nortwestern: Nortwestern University Press.

Kahneman, D., \& Tversky, A. (1979). Prospect theory: An analysis of decision under risk. Econometrica, 47 (2), $263-291$.

Kamins, M.A. (1990). An investigation into the "Match-Up" hypothesis in celebrity advertising: When beauty may be only skin deep. Journal of Advertising, 19 (1), 4-13.

Kamins, M.A., \& Gupta, K. (1994). Congruence between spokesperson and product type: A matchup hypothesis perspective. Psychology and Marketing, 11 (6), 569-586

Kassarjian, H.H. (1977). Content analysis in consumer research. Journal of Consumer Research, 4, 8-18

King, B.G., \& Soule, S.A. (2007). Social movements as extra-institutional entrepreneurs: The effect of protests on stock price returns. Administrative Science Quarterly, 52 (3), 413-442.

Kitzinger, J. (1995). Introducing focus groups. British Medical Journal, 311 (7000), 299-302.

Kozinet, R.V., \& Handelman, J. (1998). Ensouling consumption: A netnographic exploration of the meaning of boycotting behavior. Advances in Consumer Resaearch, 25, 475-480.

Krippendorff, K. (2004). Content analysis: An introduction to its methodology, $2^{\text {nd }}$ Edition. Baverly Hill CA: Sage.

Krueger, R.A. (1994). Focus groups: A practical guide for applied research, $2^{\text {nd }}$ Edition. Thousand Oaks CA: Sage.

Kunda, Z. (1999). Social cognition: Making sense of people. Cambridge M.A.: MIT Press.

Kunda, Z., \& Oleson, K.C. (1995), Maintaining stereotypes in the face of disconfirmation: Constructing grounds for subtyping deviants. Journal of Personality and Social Psychology, 68 (4), 565-579.

Lenox, M.J., \& Eesley, C.E. (2009). Private environmental activism and the selection and response of firm targets. Journal of Economics \& Management Strategy, 18 (1), 45-73.

Limbad, S.J. (2013). The application of classical conditioning theory in advertisements. International Journal of Marketing and Technology, 3 (4), 197-207.

Lofland, J. (2003). Protes: Studi tentang perilaku kelompok dan gerakan sosial. Translated by: Ashari. L. Yogyakarta: INSIST Press.

Mitchell, T.R. (1982). Expectancy-value models in organizational psychology. In Feather, N.T. (Ed.), Expectations and actions: Expectancy-value models in psychology, (pp. 293-312). Hillsdale, N.J.: Erlbaum.

Mowen, J.C., \& Minor, M. (2002). Consumer behavior, $5^{\text {th }}$ Edition. Translated by: Salim, L. Jakarta: Penerbit Erlangga.

Myers, D.G. (2008). Social psychology, $9^{\text {th }}$ Edition. New York: McGraw Hill.

Neuendorf, K.A. (2002). The content analysis guidebook. Oak CA: Sage.

O'hEocha, C., Conboy, K., \& Wang, X. (2010). Using focus groups in studies of ISD team behaviour. The Electronic Journal of Business Research Methods, 8 (2), 119-131.

Orthm U.R., \& Holancova, D. (2003-2004). Consumer response to sex role portrayal advertisement: Effects of incongruity and prejudice on emotions and attitude. Journal of Advertising, 32 (4), 77-89.

O'Sulivan, C.S., \& Durso, F.T. (1984), Effect of schema-incongruent information on memory for stereotypical attributes. Journal of Personality and Social Psychology, 47 (1), 55-70.

Ovaskainen, V., \& Kniivilä, M. (2005). Consumer versus citizen preferences in contingent valuation: Evidence on the role of question framing. Australian Journal of Agricultural \& Resource Economics, 49 (4), 379-394.

Pookulangara, S., Shephard, A., \& Mestres, J. (2011). University community's perception of sweatshops: A mixed method data collection. International Journal of Consumer Studies, 35 (4), 476-483. 
Prasetijo, R., \& Ihalauw, J.J.O.I. (2005). Perilaku konsumen. Yogyakarta: Penerbit Andi.

Rakow, L.F. (2011). Commentary: Interviews and focus groups as critical and cultural methods. Journalism and Mass Communication Quarterly, 88 (2), 416-428.

Reid, D.J., \& Reid, F.J.M. (2005). Online focus groups: An in-depth comparison of computer-mediated and conventional focus group discussions. International Journal of Marketing Research, 47 (2), 131-162.

Salkind, N.J. (2009), Teori-teori perkembangan manusia: Sejarah kemunculan, konsepsi dasar, analisis komparatif, dan aplikasi, Bandung: Nusa Media.

Schiffman, L.G., \& Kanuk L.L. (2007). Consumen behavior, $9^{\text {th }}$ Edition. New Jersey: Prentice Hall.

Sears, D.O., Freedman, J.L., \& Peplau, L.A. (1985). Social psychology, $5^{\text {th }}$ Edition. Translated by: Adryanto, M., \& Soekrisno, S. Jakarta: Erlangga.

Sen, S., Gurhan-Canli, Z., \& Morwitz, V. (2001). Withholding consumption: A social dilemma perspective on consumer boycotts. Journal of Consumer Research, 28, 399-417.

Shimp, T.A.,Stuart, E.W., \& Engle, R.W. (1991). A program of classical conditioning experiments testing variations in the conditioned stimulus and context. Journal of Consumer Research, 18, 1-12.

Singer, B.D. (1983). The case for using "Real People" in advertising. Business Quarterly, 48, 32-37.

Smith, N.C., \& Cooper-Martin, E. (1997). Ethics and target marketing: The role of product harm and consumer vulnerability. Journal of Marketing, 61, 1-20.

Stuart, E.W., Shimp, T.A., \& Engle, R.W. (1990). Classical conditioning of negative attitudes. Advances in Consumer Research, $17,536-540$

Taylor, S.E., Peplau, L.A., \& Sears, D.O. (2009). Social psychology, $12^{\text {th }}$ Edition. Translated by: Wibowo, T.B.S. Jakarta: Kencana.

Till, B.D., \& Busler, M. (2000). The match-up hypothesis: physical attractiveness, expertise, and the role of fit on brand attitude, purchase intent and brand belief. Journal of Advertising, 29, 1-13.

Till, B.D., Stanley, S.M., \& Priluck, R. (2008). Classical conditioning and celebrity endorsers: An examination of belongingness and resistance to extinction. Psychology and Marketing, 25 (2), 179-196.

Tinsley, H.E.A., \& Weiss, D.J. (2000). Interrater realibility and agreement. In: Tinsley H.E.A., and Brown, S.D. (Ed.), Handbook of applied multivariate statistics and mathematical modeling, (pp. 95-124). San Diego CA: Academic Press.

Tversky, A., \& Kahneman, D. (1992). Advances in prospect theory: Cumulative representation of uncertainty. Journal of Risk and Uncertainty, 5, 297-323.

Visentim, M., Colucci, M., \& Marzocchi, G.L. (2013). Forum: Brand measurement scales and underlying cognitive dimensions. International Journal of Market Research, 55 (1), 43-57.

Vroom, V.H. (1964). Work and motivation. New York: Wiley.

Wahyuni, S. (2012). Qualitative research method: Theory and practice. Jakarta: Penerbit Salemba Empat.

Wibowo, I. (2009). Sikap. In: Sarwono, S.W., \& Meinarno, E.A. (Ed.), Psikologi social, (pp. 79-102). Jakarta: Salemba Humanika.

Yarmey, D.A. (1993), Stereotypes and recognition memory for faces and voiced of good guys and bad guys. Applied Cognitive Psychology, 7, 419-431 


\begin{tabular}{|c|l|l|}
\hline 1. & Title of Program & $: \ldots$ \\
\hline 2. & Day & $: \ldots$ \\
\hline 3. & Date & $: \ldots$ \\
\hline 4. & Name of Broadcaster & $: \ldots$ \\
\hline 5. & Topic & $: \ldots$ \\
\hline 6. & Contacted Phone Number & $: \ldots$ \\
\hline 7. & Contacted Mobile Number & $: \ldots$ \\
\hline
\end{tabular}

\begin{tabular}{|c|c|c|}
\hline 1. & Format of programC & $\begin{array}{l}\square \text { Interactive } \\
\square \text { Interview } \\
\square \text { Mix }\end{array}$ \\
\hline 2. & Language used by informants & $\begin{array}{l}\square \text { Indonesia } \\
\square \text { Java } \\
\square \text { Mix }\end{array}$ \\
\hline 3. & Number of informants giving comments/ opinion & $\begin{array}{l}\square \text { Male }=\ldots \\
\square \text { Female }=\ldots\end{array}$ \\
\hline 4. & $\begin{array}{l}\text { Broadcaster asks informants' attitude to the cancelation of Lady Gaga's } \\
\text { concert }\end{array}$ & $\begin{array}{l}\square \text { Yes } \\
\square \text { No }\end{array}$ \\
\hline 6. & $\begin{array}{l}\text { Broadcaster is neutral, gives equal opportunities to all informants, who } \\
\text { either like or dislike with the cancelation of Lady Gaga's concert }\end{array}$ & $\begin{array}{l}\square \text { Yes } \\
\square \text { No }\end{array}$ \\
\hline 6. & $\begin{array}{l}\text { Broadcaster is independent, does not lead informans' agreement or } \\
\text { disagreement with the cancelation of Lady Gaga's concert.. }\end{array}$ & $\begin{array}{l}\square \text { Yes } \\
\square \text { No }\end{array}$ \\
\hline 7. & $\begin{array}{l}\text { Informants' attitude is divided into 2: agreement and disagreement with } \\
\text { the cancelation of Lady Gaga's concert }\end{array}$ & $\begin{array}{l}\square \text { Yes } \\
\square \text { No }\end{array}$ \\
\hline 8. & $\begin{array}{l}\text { Informants give clear reasons of agreement or disagreement with the } \\
\text { cancelation of Lady Gaga's concert }\end{array}$ & $\begin{array}{l}\square \text { Yes } \\
\square \text { No }\end{array}$ \\
\hline 9. & Some informants quoted opinions from previous informants & $\begin{array}{l}\square \text { Yes } \\
\square \text { No }\end{array}$ \\
\hline 10. & $\begin{array}{l}\text { Disagreeing Informans are those who 'feel' direct impact from the } \\
\text { cancelation of Lady Gaga's concert }\end{array}$ & $\begin{array}{l}\square \text { Yes } \\
\square \text { No }\end{array}$ \\
\hline 11. & $\begin{array}{l}\text { Disagreeing informans are those who feel that individual incentives are } \\
\text { more important than collective incentive. }\end{array}$ & $\begin{array}{l}\square \text { Yes } \\
\square \text { No }\end{array}$ \\
\hline 12. & $\begin{array}{l}\text { Disagreeing informans consider the credibility of the sponsor who appeals } \\
\text { prohibition. }\end{array}$ & $\begin{array}{l}\square \text { Yes } \\
\square \text { No }\end{array}$ \\
\hline 13. & Disagreeing informans think that Indonesia's image will be impacted. & $\begin{array}{l}\square \text { Yes } \\
\square \text { No }\end{array}$ \\
\hline 14. & $\begin{array}{l}\text { Disagreeing informans think that there is a majority-minority consideration } \\
\text { in the process of permit for Lady Gaga's concert. }\end{array}$ & $\begin{array}{l}\square \text { Yes } \\
\square \text { No }\end{array}$ \\
\hline 15. & Agreeing informans think that morality is very important & $\begin{array}{l}\square \text { Yes } \\
\square \text { No }\end{array}$ \\
\hline
\end{tabular}




\begin{tabular}{|c|l|c|}
\hline 16. & $\begin{array}{l}\text { Agreeing informans think that their disagreement is directed to the action } \\
\text { of Lady gaga. }\end{array}$ & $\begin{array}{l}\square \text { Yes } \\
\square \text { No }\end{array}$ \\
\hline 17. & $\begin{array}{l}\text { Agreeing informants think that freedom should be limited.. } \\
\square \text { Yes } \\
\square \text { No }\end{array}$ \\
\hline 18. & $\begin{array}{l}\text { Agreeing informants think that larger damage can be prevented by the } \\
\text { cancelation of Lady Gaga's concert }\end{array}$ & $\begin{array}{l}\square \text { Yes } \\
\square \text { No }\end{array}$ \\
\hline
\end{tabular}




\begin{tabular}{lll}
\hline 1. & Title of Program & $:$ write the program title \\
\hline 2. & Day & $:$ twrite the day when the program broadcast \\
\hline 3. & Date & $:$ write the date when the program broadcast \\
\hline 4. & Name of Broadcaster & $:$ write the name of program broadcaster \\
\hline 5. & Topic & $:$ write the program topic \\
\hline 6. & Contacted Phone Number & $:$ write the program phone number to give direct opinion \\
\hline 7. & Contacted Mobile Number & $:$ write the program HP number to give opinion via SMS \\
\hline
\end{tabular}

1. Format of program

Interactive: involving talking and working $\quad \square 1$ together

Interview: aformal meeting at which someone is asked questions

2. Language used by informants $\quad$ Clear enough $\quad \square$

$\square 0$

3. Number of informants giving comments $\quad$ Clear enough $\quad \square 1$

/ opinion $\quad \square 0$

4. Broadcaster asks informants' attitude to $\quad$ Clear enough $\quad \square 1$ the cancelation of Lady Gaga's concert $\quad \square 0$

6. Broadcaster is neutral, gives equal $\quad$ Neutral: not supporting any of the people or $\quad \square 1$ opportunities to all informants, who $\quad$ informants involved in an argument. $\square 0$ either like or dislike with the cancelation of Lady Gaga's concert

6. Broadcaster is independent, does not lead informans' agreement or Independent: existing separately and not $\quad \square 1$ influenced by other people. $\quad \square 0$ disagreement with the cancelation of Lady Gaga's concert.

7. Informants' attitude is divided into 2 : agreement and disagreement with the

Clear enough $\quad \square 1$ cancelation of Lady Gaga's concert

8. Informants give clear reasons of agreement or disagreement with the

Reason: a fact that makes it right or fair for $\quad \square$ informant to do something. cancelation of Lady Gaga's concert

9. Some informants quoted opinions from previous informants

Quoted: to repeat exactly what someone else

has said.

10. Disagreeing Informans are those who

Clear enough 'feel' direct impact from the cancelation of Lady Gaga's concert.

11. Disagreeing informans are those who feel that individual incentives are more important than collective incentive.

Collective incentives are related to the

$\square 1$ achievement of collective objectives. They are inclusive, that is when the objectives are realized, and everybody will get benefits including those without any contribution (free rider). On the contrary, selective incentives influence those participate in a collective action 
12. Disagreeing informans consider the credibility of the sponsor who appeals prohibition.

13. Disagreeing informans think that Indonesia's image will be impacted.

14. Disagreeing informans think that there is a majority-minority consideration in the process of permit for Lady Gaga's concert.

15. Agreeing informans think that morality is very important.
Credibility: the quality of deserving to be believed and trusted.

$\square 0$

Image: a picture that you have in your mind. $\quad \square 1$

Minority: agroup of people of a different race or $\quad \square 1$ religion that most people in a country. $\quad \square 0$

Morality: beliefs or idea about what is right and

$\square 1$ wrong and about how people should behave.

16. Agreeing informans think that their Action: something that Lady Gaga does.

$\square 1$ disagreement is directed to the action of Lady gaga.

17. Agreeing informants think that freedom should be limited.

Freedom: the right to do what you want without $\square 1$ being controlled or restricted.

18. Agreeing informants think that larger Damage: a bad effect on something. damage can be prevented by the cancelation of Lady Gaga's concert. 
Apendix 3. Inter-coder Reliability

\begin{tabular}{cccc}
\hline No & Coder- 1 & Coder- 2 & $\begin{array}{c}\text { Value } \\
\text { Coder- } 1=\text { Coder }-2 \rightarrow 1 \\
\text { Coder }-1 \neq \text { Coder }-2 \rightarrow 0\end{array}$ \\
\hline & & & \\
1 & 1 & 1 & 1 \\
2 & 1 & 1 & 1 \\
3 & 1 & 1 & 1 \\
4 & 1 & 0 & 0 \\
5 & 1 & 1 & 1 \\
6 & 1 & 1 & 1 \\
7 & 1 & 1 & 1 \\
8 & 1 & 1 & 1 \\
9 & 1 & 1 & 0 \\
10 & 1 & 0 & 1 \\
11 & 1 & 1 & 0 \\
12 & 1 & 0 & 1 \\
13 & 1 & 1 & 1 \\
14 & 1 & 1 & 1 \\
15 & 1 & 1 & 1 \\
16 & 1 & 1 & 1 \\
17 & 1 & 1 & 1 \\
18 & 1 & 1 & \\
\hline
\end{tabular}

$$
\begin{aligned}
R & \frac{2\left(\mathrm{C}_{1,2}\right)}{\mathrm{C}_{1} \mathrm{C}_{2}} \\
& =\frac{2(16)}{18 \quad 18} \\
& =0.89
\end{aligned}
$$

